\title{
TATARZY KRYMSCY - NARÓD CZY MNIEJSZOŚĆ ETNICZNA: W POSZUKIWANIU NOWEJ DROGI ODRODZENIA NARODOWEGO
}

\author{
THE CRIMEAN TATARS - A NATION \\ OR AN ETHNIC MINORITY: IN SEARCH \\ FOR A NEW WAY OF NATIONAL REVIVAL
}

\begin{abstract}
The Russian Empire, increasing its aggressive expansion to all sites of the world, conquered the Crimean Khanate in 1783. This Khanate was the only one of its kind link connecting the European (Christian) and Asian (Islamic) civilizations. It was the state of high multilateral culture with strong - in the beginning of the New Times - secularism trends and democratic bases of social and political life (there was no serfdom, the equality of rights existed on the high level, tolerance with regard to religious and ethnic communities dominated, and these communities-minorities co-existed and developed on the Peninsula - in the Tatar Crimea - in the peace). Within the framework of the Crimean Khanate the process of ethnic genesis of the Crimean-Tatar people as an ethnic-cultural subject was completed, although many differences of tribal origin and regional character remained within this unity and expressed in the heterogeneity of the anthropologic types, of every-day life's tradition and of dialects spread between the Tatars living in the North Crimean steppe, in the Mountains (highland) and on the South Coast of the Peninsula. That ethnic community (Crimean Tatars) was a nation in the modern meaning of this word, it had its own state, intellectual elite, high organization and culture. The destruction of this state-nation by the Russian Empire and the systematic genocide if the Crimean Tatars during next two centuries, reached its culmination in
\end{abstract}

SWIETLANA CZERWONNAJA Nicolaus Copernicus University, Poland E-mail: czervona@bk.ru This work was supported by the author's own resources. No competing interests have been declared.

This is an Open Access article distributed under the terms of the Creative Commons Attribution 3.0 PL License (creativecommons.org/licenses/by/3.0/pl/), which permits redistribution, commercial and non-commercial, provided that the article is properly cited. (C) The Author(s) 2015.

Publisher: Institute of Slavic Studies, Polish Academy of Sciences [Wydawca: Instytut Slawistyki PAN] 
the act of the total deportation on May $18^{\text {th }} 1944$, are the treasons and international-large crimes. The annexation of the Crimea by the Russian Federation on March 2014 (its tearing away from the Ukrainian state and military occupation) means the continuation of this felonious policy, which the Crimean Tatars resist, displaying bravery in the very difficult condition.

Key words: national self-consciousness; the indigenous people under the threat; the annexation of the Crimea by the Russia; the resistance movement of the Crimean Tatars

Streszczenie

W 1783 roku imperium rosyjskie, którego agresywna ekspansja gwałtownie wrastała, zaanektowało Chaństwo Krymskie, które było jedynym w swoim rodzaju ogniwem łączącym cywilizacje europejską (chrześcijańską) i azjatycką (islamską), państwem o wysokiej kulturze z mocnymi trendami sekularyzacji i demokratycznymi podstawami (nie było tutaj ustroju pańszczyźnianego, na wysokim poziomie znajdowało się społeczne równouprawnienie, panowała tolerancja wobec różnych wspólnot religijnych i etnicznych, które w pokojowy sposób wspótistniały i rozwijały się na tatarskim Krymie). W ramach tego państwa dobiegł końca wielowiekowy proces etnogenezy narodu krymsko-tatarskiego, jako całokształtu etniczno-kulturowego (chociaż wewnątrz tej jednolitej wspólnoty długi czas zachowały się rozróżnienia plemienne i regionalne, co przejawiało się w różnorakości typów antropologicznych, tradycji życia codziennego, w dialektach międzystepowych zamieszkałych w górach (górskimi) i na południowym wybrzeżu Półwyspu (południowo-nadbrzeżnymi) Tatarów). Ta wspólnota była narodem (we współczesnym znaczeniu tego pojęcia), posiadającym własne państwo i wysoką kulturę, Zniszczenie tego państwa-narodu przez imperium rosyjskie i systematyczne ludobójstwo Tatarów krymskich, które osiągnęło szczyt w akcji totalnej deportacji 18 maja 1944 roku, pozostaje przestępstwem na skalę międzynarodową. Kontynuacją tej przestępczej polityki jest dokonana w marcu 2014 roku powtórna aneksja Krymu, wobec której Tatarzy krymscy stawiają stanowczy opór.

Słowa kluczowe: świadomość narodowa; naród autochtoniczny w stanie zagrożenia; rosyjska aneksja Krymu; ruch oporu Tatarów krymskich

W kontekście szerokiej problematyki antropologii narodu historyczne doświadczenie Tatarów krymskich nie jest na tyle znacznym zjawiskiem o wielkiej skali, żeby znaleźć się w centrum uwagi współczesnej nauki, myśli antropologicznej i politologii. Prawdopodobnie bardziej interesującymi z naukowego punktu widzenia i bardziej odczuwalnymi, dostrzegalnymi w wymiarze socjalno-politycznym i kulturowym (to znaczy dostrzegalnymi, jako społeczne zagrożenie, jak również, na razie jeszcze w rzadkich, wyjątkowych wypadkach, jako pozytywna perspektywa rozwoju), są tamte procesy antropologizacji (wzmocnienia czynnika i pierwiastka antropologicznego) nacjonalizmu i patriotyzmu, które mają miejsce nie w nielicznych grupach etnicznych, lecz w gigantycznych, formujących się na podstawie jedności etnicznej narodach (этнонациях, Ethnic Nations), które przywłaszczyły sobie prawo, by występować w imieniu wielomilionowej ludności największych mocarstw świata (na przykład Stanów Zjednoczonych Ameryki albo Rosji) i decydować o losach już nie takiego małego kawałka pięknej ziemi, jakim jest Półwysep Krymski, ale całej kuli ziemskiej.

Mówiąc o antropologizacji (nadaniu antropologicznego wymiaru) nacjonalizmowi i patriotyzmowi, mam na myśli te psychiczne zwroty (rodzaj uskoków geologicznych) w świa- 
domości jednostki, te subiektywnie silnie przeżywane przez człowieka uczucia osobistego współudziału, osobistego uczestnictwa w realizacji programów tak zwanego "narodowego budownictwa (нациостроительства/Nation Building) we własnym kraju albo za jego granicami - współudziału i stosunku ze znakiem „plus" albo „minus”, to znaczy w duchu podtrzymania, solidarności albo protestu, oporu, którym (tym zwrotom w świadomości indywidualnej i społecznej) zawsze towarzyszy głębokie i gorące osobiste zainteresowanie w tych sprawach, co w retoryce politycznej liderów ruchów narodowych i przywódców państw narodowych oraz w mentalności zwykłych ludzi, szeregowych uczestników, przedstawicieli mas, wciągniętych w tamte ruchy, zwyczajnie znajduje wyraz w zaimkach dzierżawczych "mój” i "nasz”: mój/nasz naród, mój/nasz kraj, moja/nasza Ojczyzna, moja/ nasza kwestia narodowa.

Pierwiastek antropologiczny jest ściśle związany z dialektyką przeciwstawnych tendencji: z jednej strony mamy tutaj do czynienia z humanizacją, ze wzmocnieniem składnika humanitarnego w programach „Nation Building”, w walce o prawa narodów (ludów); z drugiej, powstaje zagrożenie przekształcenia się, wyrodzenia świadomości narodowoetnicznej w agresywny szowinizm, ksenofobię, wrogą i niebezpieczną tak dla całego otoczenia, jak i do nosicieli tej ksenofobii, w tym tak dla zbiorowości, grupy, wspólnoty narodowo-etnicznej, i dla każdej jednostki, która staje się ofiarą agresywnej ksenofobii albo nosicielem tej siły niszczącej nie tylko osobowość, lecz samą moralność, oblicze człowieka, charakter ludzkiej jaźni.

Tym procesom towarzyszą napięcie psychologiczne, znaczny wzrost temperatury ludzkich emocji, powiedziałabym nawet, namiętności, które tworzą pożywkę dla powstania atmosfery międzynarodowych/międzyetnicznych zderzeń, wrogości, kolizji interesów, konfliktów wewnętrznych albo wychodzących za granice jednego państwa, wojen domowych i wojen między domami-państwami, wojen ojczyźnianych i zaborczych, wojen matych i wielkich (przy tym wojny małe prędko przekształcają się w wielkie, czasem nawet o światowej skali), wojen groźnych dla całej ludzkości i współczesnej cywilizacji.

Jeszcze raz powiem, że gdy coś podobnego dzieje się z licznym ludem (wielkim narodem-państwem), mającym najsilniejsze środki wpływów na swoich sąsiadów, partnerów i wrogów, aż do broni masowej zagłady łącznie, jest to zjawisko znacznie bardziej niebezpieczne, istotne jako przedmiot naukowych badań i analizy i jako obiekt zapobiegawczej polityki ze strony międzynarodowego otoczenia (w tym możliwych "sankcji”, często absolutnie koniecznych, chociaż nie zawsze efektywnych), niż powtarzające się wybuchy namiętności narodowych i buntów (nie zawsze w klasycznych formach powstań, podobnych do polskich modeli wieków XIX i XX) w stosunkowo nielicznych grupach etnicznych, nieposiadających własnej, uznanej przez wspólnotę międzynarodową państwowości. Chodzi tu o narody (ludy, grupy etniczne), które straciły swą dawną państwowość w wyniku zaborów kolonialnych, zagarnięcia ich ziemi przez mocarstwa imperialne, o narody, w których historii proces dekolonizacji i odrodzenia państwowości narodowej nie dobiegł do końca albo nawet nie powstał, oraz o ludy (grupy etniczne), które w wyniku niepomyślnych dla nich okoliczności historycznych nie potrafiły utworzyć własnych instytucji państwowych, to znaczy nie miały własnej państwowości nigdy albo miały ją w bardzo odległej przeszłości, w formach, które wydają się mitami historycznymi, legendami romantycznymi.

Jednak i tamte procesy antropologizacji (załamania, refrakcji przez pryzmat osobistych uczuć, przekonań, uświadomionych sobie obowiązków jednostki) nacjonalizmu, patriotyzmu i innych koncepcji i praktyk politycznych, ściśle związanych z pojęciami "naród" 
(„mój naród”, „moi rodacy”, „wrogowie mojego narodu”), które możemy obserwować dzisiaj w stosunkowo nielicznych wspólnotach¹, w środowisku mniejszości etnicznych i narodowych, nabierają istotne znaczenie - w tym w paradygmacie „wyzwanie - odpowiedź - wyzwanie/вызов - ответ - вызов", określając klimat społeczny w każdym europejskim (i nie tylko europejskim) państwie.

W aspekcie humanitarnym rosnąca uwaga wobec mniejszości, szacunek dla ich praw i troska o zapewnienie ich żądań, potrzeb duchowych i materialnych kształtują się, jako jeżeli jeszcze nie norma powszechna i codzienna, to w każdym razie jako moralny imperatyw kategoryczny polityki każdego cywilizowanego i demokratycznego państwa, natomiast same tamte mniejszości (niezależnie od ich liczebności) tworzą istotny składnik kulturowo-gospodarczego potencjału państwa-narodu i są obecne w każdym kraju europejskim (i nie tylko europejskim) łącznie z tymi krajami, których prawodawstwo uznaje tamte mniejszości i tworzy dla nich maksymalnie pomyślne warunki rozwoju, oraz z tymi krajami, które własnych mniejszości nie uznają, nie zauważają, ich prawa lekceważą i łamią albo minimalizują i ze wszystkich stron obcinają limit, kwote uznanych i protegowanych, lojalnych wobec tego państwa mniejszości.

W tym aspekcie, rzecz jasna, Tatarzy krymscy - tak samo jak inne bezpaństwowe nieliczne ludy europejskie - też zasługują na uwage współczesnych antropologów i politologów, ale nie ukrywamy, że ta uwaga ze strony wspólnoty międzynarodowej kolosalnie wzmacnia się przez dzisiejszą koniunkturę polityczną, a mianowicie przez fakt powtórnej rosyjskiej aneksji Krymu, w marcu 2014 roku na oczach całego świata, wbrew prawu międzynarodowemu i wbrew gwarancjom, które zawiera Memorandum, podpisane w 1994 roku w Budapeszcie przez Rosję, Stany Zjednoczone i Wielką Brytanię (Memorandum gwarantowało w imieniu trzech mocarstw nuklearnych zachowanie integralności terytorialnej Ukrainy, Białorusi i Kazachstanu, które zrezygnowały z utrzymania broni strategicznej na ich terenach, przekazując tę broń do Rosji). Rosyjska aneksja Krymu, należącego od 1954 roku do państwa ukraińskiego (do Ukraińskiej SRR, a od 1991 roku do niezależnej Ukrainy), dokonana z użyciem przymusu (sił zbrojnych Federacji Rosyjskiej zamaskowanych i w duchu fantazji Orwella o ministerstwach pokoju i miłości określonych „siłami samoobrony"), kłamstwa publicznego o wielkiej skali, organizacji i fałszowania wyników tak zwanego referendum 16 marca, bojkotowanego przez rdzenną ludność Krymu - Tatarów krymskich², stanowi groźne niebezpieczeństwo dla innych narodów i krajów, przede wszystkim Europy Wschodniej, bo rosyjska agresja (świadczą o tym wydarzenia lata - jesieni 2014 roku) nie zatrzyma się na Krymie, już dotyczy (albo dotknie w najbliższej przyszłości) całej Ukrainy, Mołdowy, Gruzji, grozi młodym niezależnym państwom - Łotwie, Estonii, Litwie, Kazachstanowi, Azerbejdżanowi, i kto wie, jak daleko pójdzie dalej na wschód i na zachód. Dlatego badania mentalności i strategii zachowania Tatarów krymskich, którzy stali się jedną z pierwszych ofiar tej wznowionej rosyjskiej agresji imperialnej, ma nie tylko aktualne znaczenie teoretyczne, historyczne (tym ważniejsze, im mniej

\section{......}

Na Krymie, na przykład, Tatarzy krymscy stanowią mniejszość. Oficjalna statystyka określa ich liczebność na 245291 osób, co daje 10,2\% ludności Krymu (patrz: Начіональний склад населення АРК та його мовні ознаки: за даними всеукраїнського перепису населення 2001 року, 2003). Nawet jeżeli te dane są zaniżone (w rzeczywistości Tatarów na Krymie na początku XXI wieku było nie mniej niż 300 tys., jasne jest zatem zatem, że tak czy inaczej mamy do czynienia z grupą nieliczną, z mniejszością).

2 „Абсурдно утверждение оккупационных властей - powiedział Dżemilew w swojej przemowie 31 marca 2014 roku na posiedzeniu Rady Bezpieczeństwa ONZ ('The Arria Formula Meeting') - что посредством референдума они [rosyjskie władze Krymu] хотели выявить волеизъявление 'крымского народа' и удовлетворить его 'право на самоопределение' в соответствии с международными нормами, ибо нет такого 'крымского народа', а право на самоопределение может принадлежать только коренному народу. А коренной народ Крыма - крымские татары - всецело бойкотировали этот референдум" (М. Джемилев, 2014). 
Europa zna Tatarów krymskich), lecz również wartość praktyczną, jako osiągnięte w nowych warunkach doświadczenie oporu wobec reżymu okupacyjnego. Doświadczenie to może się przydać innym narodom, które znajdą się w analogicznej sytuacji.

Antropologiczne koncepcje narodu (własnego narodu, narodów sąsiednich) w ujęciu i rozumieniu Tatarów krymskich - to swego rodzaju "mieszanka piorunująca”, zespół przeciwstawnych tożsamości, szorstki styk niezgadzających się nawzajem odpowiedzi na pytania „Kim jesteśmy?” i „Kim są oni?” w ich własnej świadomości, kulturze, retoryce organizacji politycznych i w "zewnętrznej” opinii publicznej. Ta głęboka niezgoda dotyczy przede wszystkim różnych etapów historycznych, różnych kontekstów politycznych, w których Tatarzy krymscy różnie odpowiadali na te podstawowe pytania ( „Kim jesteśmy?", "Kim są oni?"), i znajduje się w widocznej sprzeczności z tą całkowitą jednomyślnością, którą oni demonstrują w każdej konkretnej sytuacji, dosłownie (albo prawie dosłownie), w każdym razie w sprawach istotnych, zasadniczych, głosując, decydując, postępując jednakowo, jak jeden mąż («все как один» - trudno znaleźć dokładny odpowiednik w języku polskim). Duch zbiorowości, solidarności między rodakami, posłuszeństwa wobec własnych liderów i autorytetów, jednomyślności narodowej jest w najwyższym stopniu charakterystyczny dla Tatarów krymskich. Rozmaite przesłanki, wyjaśnienia i usprawiedliwienia $w$ ich historii, religii (islam przecież jest religią posłuszeństwa), w dramatycznej przeszłości, gdy zjednoczenie i jednomyślność (wszyscy „jak jeden mąż") - na różnych poziomach - rodziny, gminy, społeczności lokalnej, regionalnej, krajowej - były niezbędnym narzędziem wytrwania w trudnych warunkach, samoobrony. Oczywiście ten pierwiastek zbiorowości, dyscypliny, podporządkowania się jednostki woli grupy, priorytet społecznego nad osobistym, ten wyraźny priorytet "my" nad „ja" (nieważne, czego ja chcę, co myślę, uważam za prawdę ostateczną, ważne jest to, czego my wszyscy chcemy, co uważamy za prawdę, o co walczymy) są oznakami w pewnym sensie ograniczonej demokracji, osłabienia czynnika humanitarnego („wolności jaźni”), jeszcze niezupełnie dojrzałej, niezupełnie rozwiniętej świadomości narodowej, opierającej się na szerokim pluralizmie poglądów. Ale w pewnych warunkach właśnie ta ograniczoność może się stać siłą, zapewniającą mobilizację masową i efektywność ruchu narodowego.

Mówiąc o sprzecznościach tatarskich koncepcji tożsamości, mam na myśli nie tylko dynamiczne zmiany w świadomości narodowej (odpowiedź na pytania „Kim jesteśmy?" i "Kim są oni?" zmienia się w czasie; to, co wydawało się najważniejszym wczoraj, traci sens dzisiaj albo może stracić go jutro), ale również dystans między subiektywnymi interpretacjami ze strony Tatarów krymskich własnego stanu, własnej historii, roli „innych/obcych" a mniej więcej obiektywnym stanem rzeczy, faktami historycznymi. Tatarzy krymscy tak naprawdę mają swoją "Tysiąc i jedną noc" mitów, bajek historycznych, w tym związanych z ich etnogenezą, z ich losami historycznymi. Ale każda próba współczesnych badaczy, historyków, antropologów, by oddzielić wymyst, legendę stworzoną w wyobraźni od tak zwanej „prawdy historycznej”, napotyka wielkie trudności. Po pierwsze dlatego, że stereotyp tak zwanego myślenia naukowego bywa znaczniej węższy niż szeroka świadomość narodowa; w końcu Tatarzy lepiej znają własną historię, ich pamięć narodowa zachowała momenty, które tylko wydają się legendarnymi, jeżeli patrzyć na nie z "obcej” strony, i snobistyczne próby, by „poprawić” myślenie narodowe, którymi długi czas zajmowała się rosyjska "wysoka nauka” tak carskich, jak i komunistycznych i postkomunistycznych czasów, obalić legendy heroiczne, przekonać opinię publiczną, że „tego nie było” "tego nie mogło być w rzeczywistości", że to wszystko jest strefą fantazji i fikcji, pozostają nie bardzo przekonującymi, i sami Tatarzy odrzucają je właśnie, jako wymysły. 
Po drugie, jeżeli nawet udałoby się udowodnić na podstawie niewątpliwych faktów, iż ten czy ów okres w historii Tatarów krymskich (na przykład, okres rozwoju krymskiego chaństwa, okres rosyjskiej kolonizacji Krymu od końca XVIII wieku, okres rewolucji i wojny domowej, okres, kiedy istniała Krymska Autonomiczna Socjalistyczna Republika Radziecka, okres drugiej wojny światowej, okres deportacji i zesłania i tak dalej do naszych dni włącznie) wyglądał inaczej, niż rysuje tatarska pamięć narodowa, jeżeli nawet sama historia pochodzenia (etnogenezy) Tatarów krymskich nie ma nic wspólnego z subiektywnymi wersjami tego pochodzenia od Tawrów i Kimmerijców (najstarszych znanych według ich etnonimów plemion zamieszkujących półwysep Krymski) (patrz: Возгрин, 1992), nie miałoby to wielkiego znaczenia, bo najważniejsze $w$ tym procesie formowania świadomości narodowej (antropologii narodu) jest nie to, co było w odległej czy bliskiej rzeczywistości, lecz właśnie to, co przedstawicielom danego narodu wydaje się, co stało się ich wiarą, przekonaniem, bólem albo dumą, źródłem i czynnikiem ich mobilizacji i aktywnej działalności dzisiaj. Wspomnienia o tym, czego nigdy nie było, mogą odegrać w takiej mobilizacji nie mniejszą rolę niż niewątpliwe fakty historyczne. Zresztą, przy całym bogactwie wyobraźni i fantazji, wyciskającym piętno na tatarskiej świadomości narodowej, Tatarzy krymscy (ich inteligencja, elita polityczna, naukowa, twórcza, zwykli ludzi, dobrze wykształconi i wychowani nie tylko i nie tyle w szkołach, ile w rodzinach i wspólnotach tatarskich, swobodnie operują uzasadnionymi faktami historycznymi, z których "cegiełek" budują oni swój solidny dom świadomości narodowej, swoją antropologiczną wersję narodu krymsko-tatarskiego, o której nie da się powiedzieć, że stoi ona na piasku.

Postaram się przedstawić w skrócie podstawowe składniki tej wersji.

Pierwsza teza, powiedziałabym główna, na której stoi gmach świadomości narodowej, polega na przekonaniu (i nie będąc fachowcem w złożonej dziedzinie paleoetnografii, powiem jednak, że w tym przekonaniu widzę dużą wiarogodność), iż Tatarzy krymscy są aborygenami, "narodem rdzennym” (, indigenous people”) na Krymie. Oni znikąd tu nie przyszli, nie podbili Krymu, chociaż, rzecz jasna, w toku historycznego stanowienia wchłaniali do swego substratu komponenty kultur wielu narodów-przybyszy, w tym Greków starożytnych, Chazarów, Turków-Seldżuków, Gotów, Osmanów, Włochów, Mongołów założycieli imperium Czyngischana i jej zachodniej krainy - Złotej Ordy. Tutaj przeplatały się korzenie, oddziaływały nawzajem wpływy różnych kultur narodów osiadłych i koczowniczych, europejskich i azjatyckich, żadnej izolacji od śródziemnomorskiej cywilizacji i od Bliskiego Wschodu nie było. Ale cała etnogeneza Tatarów krymskich, która dobiegła końca w XIII-XIV stuleciach, odbywała się w krymskim epicentrum i w stepach północnego czarnomorskiego wybrzeża. Autochtoniczny charakter Tatarów krymskich w tym wschodnioeuropejskim regionie jest w ich świadomości rzeczą świętą, niezaprzeczalną, oni postrzegają Krym jako swoją jedyną ojczyznę etniczną i historyczną.

Wiadomo, że wokół pojęcia "rdzennego narodu ( „коренного народа”) toczy się wiele dyskusji we współczesnej etnologii, politologii i antropologii kulturowej. Podstawowe wnioski, które można wyciągnąć z tych dyskusji, sprowadzają się do dwóch podejść do tej sprawy: albo za autochtoniczną grupę etniczną (rdzenny naród) możemy przyjąć tę grupę, czyja etnogeneza dobiega końca (nie zaczyna się, ale właśnie dobiega końca) na tej ziemi, w tym regionie, albo ten lud (plemię, konglomerat plemion), który/które zamieszkiwały ten kraj do jego imperialnej kolonizacji (dotyczy to przede wszystkim ludów kontynentu afrykańskiego, czyja etnogeneza, może jeszcze nie dobiegła końca do momentu imperialnego natarcia, zaborów, europejskiej kolonizacji ich ziemi). Otóż Tatarzy krymscy z obydwóch punktów widzenia są rdzennym narodom Krymu: ich długa historyczna etno- 
geneza dobiegła końca na tej ziemi, i oni mieszkali na tej ziemi (i tworzyli większość ludności Krymu, prawie 90\%) aż do momentu rosyjskiej agresji i kolonizacji Krymu (krwawe natarcia, wyprawy ciągną się przez cały wiek XVIII i znajdują swój szczyt w Manifeście cesarzowej Katarzyny Wielkiej z 8 kwietnia 1783 roku, który deklaruje (wbrew wszystkim prawom, normom stosunków międzynarodowych, osiągniętym i podpisanym wcześniej porozumieniom, wbrew zdrowemu rozsądkowi i logice, bo nic wspólnego z Rosją krymska kultura i cywilizacja nie miała, i co najważniejsze, wbrew woli ludności krymsko-tatarskiej) przynależność Krymu do Rosji.

Jak wydawałoby się na pierwszy rzut oka, sprawy czysto teoretyczne albo należące do bardzo odległej historii (kogo ujmować - nie ujmować za naród rdzenny, kiedy i w jaki sposób dobiegła końca etnogeneza narodu krymsko-tatarskiego) są aktualne w naszych czasach, w strategii krymsko-tatarskiego ruchu narodowego. Domagając się formalnego (jeszcze przez prawodawstwo Ukrainy) uznania narodu krymsko-tatarskiego za naród rdzenny, autochtoniczny, liderzy i ideologowie ruchu krymsko-tatarskiego - w organicznym, logicznym związku z tym faktem - wysuwają postulat o prawie Tatarów krymskich do samostanowienia państwowego na ich ziemi ojczystej, mówią o konieczności nadania im statusu narodu walczącego o dekolonizację.

Samostanowienie państwowe Tatarów krymskich w różnych czasach historycznych przedstawia się w różnych formach - od samodzielnego Krymskiego Ułusu Złotej Ordy XIII-XV wieków do niepodległego Chaństwa Krymskiego, powstałego na przełomie wieków XV i XVI i zniszczonego w wyniku rosyjskiej agresji pod koniec XVIII wieku; od ogłoszonej przez pierwszy Krymsko-Tatarski Kongres Narodowy (Kurułtaj) w grudniu 1917 roku Demokratycznej Republiki Krymu, która istniała krótki czas, do wiosny 1918 roku i została utopiona w krwi w wyniku inwazji bolszewickiej, wreszcie do Republiki Autonomicznej - narodowo-terytorialnej autonomii Tatarów krymskich na Krymie w ramach innego, większego państwa, bądź to Federacja Rosyjska, Ukraina, w idealnej perspektywie możliwie Turcja. Nawet utworzoną na podstawie Leninowskiego dekretu z 18 października 1921 roku Krymską ASSR, która była niczym innym jak tylko farsową formą, bladym cieniem prawdziwego narodowego samostanowienia, Tatarzy krymscy długi czas postrzegali jako własne państwo, do którego prawo wynikało z ich statusu jedynej rdzennej ludności Krymu (pozostali jego mieszkańcy, niezależnie od tego, czy tworzą oni małe albo gigantyczne w swojej arytmetycznej liczebności grupy, są przybyszami, nie są rdzenną ludnością Krymu - oni zjawili się tutaj w różnych wiekach, jako już uformowane $w$ innych regionach grupy etniczne) i dlatego żadnego prawa do samostanowienia na ziemi krymskiej nie mają. Wyjątek Tatarzy krymscy robią tylko dla dwóch grup etnicznych - Karaimów (Karajów) i Krymczaków, uważając obie te grupy, tak samo jak sami siebie, za rdzenne ludy półwyspu krymskiego. Ale ponieważ te grupy są po prostu mikroskopijne (jeszcze na początku XX wieku liczono je w tysiącach, po wojnie już w setkach, teraz liczba ta spadała jeszcze bardziej), to mówi się najczęściej nie o trzech dodatkowych rdzennych narodach mających na Krymie prawo do samostanowienia państwowego, ale o jednym narodzie krymsko-tatarskim i bliskich im Krymczakach i Karaimach, których języki należą do tej samej turskiej (tureckiej) rodziny językowej co język krymsko-tatarski.

Pierwsza najważniejsza deklaracja polityczna (O suwerenności narodu krymsko-tatarskiego), którą jednogłośnie uchwalił 28 czerwca 1991 roku (po dokonanej repatriacji Tatarów krymskich z miast zesłania) Drugi Narodowy Kongres (Kurułtaj narodu krymsko-tatarskiego), głosiła: 
Krym jest narodowym terytorium krymsko-tatarskiego narodu. Tylko na tym terytorium ten naród posiada prawo samostanowienia tak, jak postrzega je prawo międzynarodowe. Polityczne, gospodarcze, duchowe i kulturowe odrodzenie narodu krymsko-tatarskiego jest możliwe tylko w jego suwerennym państwie. Do tego celu będzie dążyć naród krymsko-tatarski, wykorzystując wszystkie środki przewidziane w prawie międzynarodowym.

Крым является национальной территорией крымскотатарского народа, на которой только он обладает правом на самоопределение так, как оно изложено в международных правовых актах, признанных мировым сообществом. Политическое, экономическое, духовное и культурное возрождение крымскотатарского народа возможно только в его суверенном национальном государстве. К этой цели будет стремиться крымскотатарский народ, используя все средства, предусмотренные международным правом (Губогло \& Червонная, 1992, s. 109).

Jednocześnie w odezwie do ludzi wszystkich narodowości, do przedstawicieli wszystkich mniejszości narodowych i etnicznych, zamieszkałych na Krymie, Kurułtaj podkreślał pokojowy i humanitarny charakter powrotu narodu krymsko-tatarskiego do swojej Ojczyzny:

Kurultaj w imieniu narodu krymsko-tatarskiego oświadcza: Wracając do swojej Ojczyzny, niesiemy ze sobą dobro dla wszystkich ludzi mieszkających na Krymie. Nie mamy zamiaru wyrządzić komuś z was krzywdy, nie targamy się na wasze mienie, na wasze duchowe, religijne, kulturowe i polityczne prawa. Szanujemy narodowe uczucia i godność wszystkich ludzi. Zawsze podtrzymywaliśmy przyjacielskie związki ze wszystkimi grupami narodowymi zamieszkującymi na Krymie.

Курултай от имени крымскотатарского народа заявляет: Возвращаясь на свою родину, мы несем с собой добро для всех людей, живущих в Крыму. У нас нет намерения нанести ущерб кому-либо из вас, мы не покушаемся на ваши имущественные, духовные, культурные, религиозные, политические и другие права. Мы уважаем национальные чувства и человеческое достоинство всех людей. Мы всегда поддерживали традиционно дружественные отношения со всеми национальными группами, проживающими в Крыму (Губогло \& Червонная, 1992, s. 113).

Ale głównym motywem tej odezwy było stwierdzenie:

Krym jest Ojczyzną Tatarów Krymskich, innej ziemi nie mamy.

Крым является родиной крымских татар, другой земли у нас нет (Губогло \& Червонная, 1992, s. 113).

W krytycznej sytuacji wiosną 2014 roku Kurułtaj i Narodowy Samorząd (Milli-Medżlis) narodu krymsko-tatarskiego znów podjął zadanie utworzenia na Krymie suwerennej narodowo-terytorialnej autonomii Tatarów krymskich. Referendum 16 marca, bojkotowane przez Tatarów krymskich, przeprowadzone siłami rosyjskich okupantów, było uznane za przestępcze i sprzeczne z prawem. 29 marca 2014 roku Kuruttaj na swoim ostatnim posiedzeniu uchwali projekt odbudowy narodowo-terytorialnej autonomii Tatarów krymskich w granicach całego półwyspu (bez wskazania na państwo, w którego ramach będzie istnieć ta autonomia (to znaczy w Rosji albo w Ukrainie) i polecał Medżlisowi przystąpić do realizacji tego projektu. Było to w warunkach rosyjskiej okupacji przedsięwzięcie absolutnie niemożliwe, nierealne, fantastyczne, jak krzyk rozpaczy. Jakie polecenie mógł wypełnić Medżlis, już zniszczony fizycznie i moralne, Medżlis, którego kierownictwo (lider narodu krymsko-tatarskiego Mustafa Dżemilew i przewodniczący Medżlisu Refat Czubarow) dostali od rosyjskiego rządu zakaz wstępu na Krym, znalazło się na emigracji kijowskiej? Ale należy pamiętać o tym, że hasła państwowego samostanowienia, opierające się na teorii autochtonicznego statusu narodu krymsko-tatarskiego, brzmią z nową siłą, powstają w każdej nowej krytycznej sytuacji i działają dość efektywnie jako narzędzie polityczne. Nie zawieszając $w$ żadnym wypadku ludzkich praw i swobód wszystkich pozostałych 
mieszkańców Krymu, przedstawicieli różnych grup migrantów, przybyszy dawnych i nowych czasów, Tatarzy krymscy za nikim z nich nie uznają prawa samostanowienia na Krymie, rozwiązania losów Krymu bez udziału w tym i wbrew woli rdzennego narodu.

Drugi, można powiedzieć, zrąb, na którym utrzymuje się krymsko-tatarska świadomość narodowa - to przekonanie, że Tatarzy krymscy, w odróżnieniu od wszystkich innych mieszkańców Krymu, nie są mniejszością etniczną lub narodową, ale są narodem. Przekonanie to nie odpowiada realnej sytuacji dnia dzisiejszego oraz teoriom narodu jako wspólnoty, która utworzyła własne państwo, rozpowszechnionym przede wszystkim w etnologii i antropologii amerykańskiej, zgodnie z której standardami formuje się typowa terminologia (Organizacja Narodów Zjednoczonych występuje jako organizacja państw, natomiast lud, niemający swej państwowości, nie jest postrzegany jako naród). Na mapie współczesnego świata nie ma państwa krymsko-tatarskiego, ale niech ktoś spróbuje przekonać krymskich Tatarów, iż nie są narodem, ale ludem bezpaństwowym, mniejszością, grupą etniczną. Tatar krymski nie będzie słuchać żadnych argumentów tego rodzaju, absolutnie przekonany w tym, że należy do Narodu. Takie przekonanie opiera się na pamięci historycznej o wielkim i sławnym Chaństwie Krymskim, które istniało w Europie Wschodniej od XV do końca XVIII wieku (patrz: Гайворонский, 2003), wyrosło z tradycji Krymskiego Ułusu Złotej Ordy XIII-XIV wieków) i zostało zlikwidowane (podbite) przez Imperium Rosyjskie prawie jednocześnie z Rzecząpospolitą Polską, z Carstwem Gruzińskim, z emiratami azerbejdżańskimi, z Hetmaństwem Ukraińskim. Jeżeli w XX wieku odrodziły się, jako państwa niezależne, i stali narodami Polacy, Litwini, Gruzini, Azerowie, Ukraińcy i tak dalej, to dlaczego nie Tatarzy krymscy? Swój obecny stan postrzegają oni jako sytuacje prowizoryczną, przejściową, jako przeddzień historycznego odrodzenia państwa krymsko-tatarskiego (niekoniecznie w formach monarchii, chaństwa, chociaż zanotuję na marginesie, że tradycja następstwa tronu w domu Garejów trwa stale na emigracji, a dzisiejszy następca tronu mieszka w Londynie). Złota legenda wspaniałego krymskiego chaństwa trwa i żyje w krymsko-tatarskiej literaturze, w nauce historycznej, w dziennikarstwie, w pamięci zbiorowej, narodowej. Zresztą to nie tylko legenda, a być może wcale nie legenda, lecz prawda historyczna, długi czas ukrywana i fałszowana przez propagandystów rosyjskich, którzy starali się przedstawić Chaństwo Krymskie jako gniazdo zbójeckie, rozsadnik barbarzyństwa, kraj zacofany, pasożytniczy. Nic podobnego. Aż do samego końca XVIII wieku było to państwo odpowiadające postępowym standardom europejskiej państwowości, ze wspaniałą organizacją administracji, wojska, z dość demokratycznym systemem rządowym, z własną narodową elitą, arystokracją. To było państwo wysokiej kultury, na jego terenie powstały najstarsze europejskie uniwersytety, ono miało bogatą literaturę, kulturę teatralną, kulturę pisma i druku. Naród tego państwa nigdy nie doznał ustroju pańszczyźnianego, Tatarzy krymscy - wojskowi, chłopi, pasterze, hodowcy winorośli, budowniczy, artyści, rzemieślnicy - zawsze byli ludźmi wolnymi. Oczywiście to państwo brało udział w licznych wojnach średniowiecznych i nowoczesnych, często z wielkim sukcesem (tatarska jazda była najsilniejszą w Europie), ale wkład tego państwa do cywilizacji ludzkiej polega nie na wojnach, a na wielkich gospodarczych i kulturowych osiągnięciach pracowitego ludu krymsko-tatarskiego. Cudowne ogrody, winnice, plantacje tytoniu, unikatowy system zaopatrzenia w wodę całego półwyspu, słynne pomniki architektury, w tym meczety i pałace (saraje), bogate biblioteki, zbiory książek i utworów artystycznych - takie było oblicze Krymskiego Chaństwa. Przynależność do cywilizacji islamskiej, ściśle związki z kulturą osmańską odróżniały je od większości królestw i carstw Wschodniej Europy, ale było to państwo wysokiej tolerancji duchowej, żadna inna religia 
i konfesja nie była poddana tutaj prześladowaniom, a Tatarzy krymscy nikomu nie narzucali islamu przymusowo.

Jeżeli Tatarzy krymscy są nosicielami takich państwowych tradycji, przerwanych tylko w wyniku agresji imperialnej mocarstwa rosyjskiego, i jeżeli oni dążą do odrodzenia, odbudowy swego państwa, kto może odmówić im prawa nazywać się i być narodem .

Wreszcie trzeci ważny czynnik świadomości narodowej Tatarów krymskich, niestety raczej bolesny niż tworzący grunt dla dumy narodowej, polega na tej urazie (głębokiej traumy narodowej), której doznali już po pierwszej rosyjskiej aneksji i która wycisnęła swoje piętno na charakterze narodowym, będąc źródłem tego potencjału ruchu oporu, który żyje w środowisku krymsko-tatarskim.

Tatarski nowoczesny charakter formował się i hartował w stałej konfrontacji z tak zwanym „Krymem rosyjskim”.

18 marca 2014 roku prezydent Federacji Rosyjskiej Putin powiedział: „Krym będzie rosyjski, Krym będzie ukraiński, Krym będzie tatarski, ale nigdy nie będzie "banderowski'". Nie wiadomo, co miał na myśli, mówiąc o Krymie "banderowskim”, bo tak zwani "banderowscy", jeżeli nawet istnieją na Ukrainie, żadnej działalności na Krymie nie rozwijali. Zresztą nigdzie w innym miejscu na świecie nie istniało jeszcze państwo „banderowskie” i nie możemy wyobrazić sobie, jakby ono w rzeczywistości wyglądało.

Natomiast, co to znaczy "Krym rosyjski” i na jakich podstawach moralnych, społecznych, politycznych i kulturowych formuje sie tu i szaleje patriotyzm rosyjski (w ideologii imperialnej rządzącej elity i w mentalności pozbawionego praw, ale agresywnego tłumu), wiemy doskonale.

Rosyjski Krym - to wypalone pole dla innych kultur i narodów, które nie utożsamiają siebie z "wielką Rosją". To miliony Tatarów krymskich wygnanych z ich ziemi ojczystej, deportowanych do martwych zon cesarskiego albo komunistycznego GUŁAGu, zmuszonych szukać ratunku w emigracji, w mohadżerstwie, przede wszystkim w Turcji3.

Rosyjski Krym - to zniszczone winnice, wycięte ogrody, zaniedbane studnie, które w Chaństwie Krymskim składały się na unikatowy pełnowartościowy system zaopatrzenia półwyspu w wodę. To jednakowo nędzne wsie rosyjskich chłopów przepędzonych na Krym z różnych obwodów Imperium rosyjskiego i ostentacyjnie luksusowe wille rosyjskiej arystokracji na Południowym wybrzeżu. Wspaniałą (dokładną) charakterystykę pseudo-rosyjskiej kultury, krzewionej na Krymie, potrafił dać poeta Maksymilian Wołoszyn:

Zamiast cudownych pysznych miast z Tysiąca i Jednej Nocy Rosjanie zbudowali na Krymie kilka ubogich, nędznych powiatowych miast według rosyjskich szablonów i w duchu potiomkinowskiego romantyzmu określili je pseudo-klasycznymi nazwami - Sewastopol, Symferopol, Eupatoria. Całe starożytne państwo Gotów, od Bałakławy do twierdzy w Ałuszcie zabudowano siejącymi zgorszenie cesarskimi willami podobnymi do kolejowych bufetów i domów publicz-

\section{......}

3 Według danych szacunkowych w Turcji do dziś zamieszkują więcej niż 2 mln Tatarów krymskich - potomków tych mohadżerów, których Rosja wypierała z Krymu tak bezpośrednio po aneksji dokonanej w 1783 roku, jak również w dziesięcioleciach następnych, gdy przy każdych własnych porażkach i kryzysach szukała „winnych", i tymi „winnymi” odpowiedzialnymi za rosyjską miernotę na polach alki wojennej albo w sprawach gospodarczych zawsze stanowili Tatarzy krymscy, postrzegani przez Rosje, jako "zdrajcy”, wrogowie, "buntownicy” - często zarzuty te były niesłuszne). Już pod koniec XVIII wieku około 100000 Tatrów krymskich pozostawionych bez ziemi, bez środków do życia, prześladowani za wiarę islamską, zmuszeni byli zostawić własną ojczyznę, która powoli przekształcała się W „Krym rosyjski” (patrz: Маркевич, 1928, s. 389). W wyniku porażki w wojnie krymskiej lat 1853-1856 "Rosja-matuszka” bezsilna wobec mocarstw europejskich, skierowała swą wściekłość na własnych poddanych, przede wszystkich Tatarów krymskich, i wtedy jeszcze około 300000 Tatarów zmuszonych były przesiedlić się na przeciwległe brzegi Morza Czarnego (Никольский, 1929, s. 26). Z półmilionowej tatarskiej ludności Krymu (1783) ostała się mniej niż czwarta część. Naród tracił ziemię, prawa, swoje dziedzictwo kulturowe, swych najlepszych synów. Udział Tatarów W ludności Krymu między 1783 a 1917 rokiem spadt z 90 do 25\%. Przeksztatcili się oni W „mniejszość etniczną" we własnym kraju. 
nych. Całe to muzeum złego smaku rywalizujące z europejskimi burdelami i spelunkami francuskiej Riwiery prawdopodobnie pozostanie na zawsze jedynym pomnikiem rosyjskiej epoki na Krymie...

Взамен пышных городов из Тысяча и Одной Ночи русские построили несколько убогих уездных городов по российским трафаретам и частью из потемкинского романтизма, частью для Екатерининской рекламы назвали их псевдоклассическими именами - Севастополем, Симферополем, Евпаторией. Древняя Готия от Балаклавы до Алустона застроилась непристойными императорскими виллами в стиле железнодорожных буфетов и публичных домов (...). Этот музей дурного вкуса, претендующий на соперничество с международными европейскими вертепами на Ривьере, очевидно, так и останется в Крыму единственным монументальным памятником „русской эпохи” (Волошин, 1992, ss. 67-68).

"Rosyjski Krym" - to Denikin i baron Wrangel4, którzy spodziewali się odbudować na tym skrawku ziemi monarchię i rządzić krajem, nie zauważając jego narodu rdzennego, i to jeszcze straszniejsze hordy bolszewickie, które zalały Krym i, upojone zwycięstwem, dobijały na swojej drodze nie tylko resztki wojska białogwardyjskiego, cały jego korpus oficerski, ale wszystko, co jeszcze miało godność duchową, było zdolne do politycznej działalności samodzielnej i odróżniało się od krwawo-szarej masy zwycięzców pod wodzą Frunzego ${ }^{5}$.

Rosyjski Krym - to pijani matrosi sewastopolscy, którzy dokonywali barbarzyńskich samosądów nad oficerami i bez żadnych sądów wyrzynali cywilną ludność miast i wiosek6. Mówiąc o „Krymie rosyjskim”, jako nosicielu wojującego rosyjskiego patriotyzmu, którego ostoją i bazą wypadową zawsze miało służyć „miasto rosyjskiej chwały wojennej" Sewastopol, nie możemy nie zauważyć, między innymi, jak śmiesznie brzmi samo to określenie, zawierające w sobie przedstawienia o chwale i sławie (rosyjska władza nawet oficjalnie nadała Sewastopolowi w 1945 roku tytuł "miasta-bohatera”). Ten trochę dziwaczny „bohater" przegrał, jak wiadomo, Wojnę Krymską, nie pozostawiając Rosji żadnej szansy pozostać czcigodnym mocarstwem pośród europejskich mocarstw XIX wieku; w roku 1918 w panicznym strachu przed interwencją niemiecką zatopił własną marynarke wojenną7; w roku 1941 kapitulował przed niemiecko-faszystowskimi zaborca-

\section{$\cdots \cdot \cdots$}

4 Krym stał areną walki „czerwonych” i „białych” podczas Wojny Domowej. Ochotnicza armia pod komendą generała A.I. Denikina (1872-1947) trzymała Krym w swoich rękach od lipca 1919 roku. W marcu 1920 roku na zmianę reżymowi Denikina przyszła dyktatura P.N. Wrangla (1878-1928), który próbował stworzyć tutaj coś w rodzaju pola doświadczalnego odrodzenia Imperium Rosyjskiego niby na podstawach demokratycznych. Tatarom Krymu ta "demokracja” niczego dobrego nie niosła i nie obiecywała, a naród tatarski nie popierał białogwardyjską władzę na Krymie.

5 Michaił Frunze (1885-1925) dowodził południową grupą sił zbrojnych Armii Czerwonej, której odziały przerwały linię obrony Przesmyku Perekopskiego i wtargnęły do Krymu w listopadzie 1920 roku. Ofiarami rozwiązanego na półwyspie czerwonego terroru stali się nie tylko oficerowie i żołnierze wojsk białogwardyjskich, którzy złożyli broń, ale również szerokie koła ludności cywilnej (mieszkańcy Krymu wszystkich narodowości) i nawet byli sprzymierzeńcy, w tym przywódcy i szeregowi członkowie tatarskiej socjalistyczno-demokratycznej Narodowej partii („Milli-Firka”), która współpracowała z bolszewikami podczas Wojny Domowej.

6 Mrożące krew w żyłach obrazy tego, co robili sewastopolscy matrosy na Krymie, opisat, opierając na źródłach dokumentalnych i świadectwach naocznych świadków, Edige Kırımal. Przypomnimy tylko jeden z tych „Czynów bohaterskich", który miał miejsce wiosną 1918 roku.

„In Sewastopol wurden die Verhafteten nach kurzem Verhör in den Kielraum des Transporters ,Truvor' gebracht, innnerhalb von 3 Tagen 800 Mann. Sie bekamen kein Essen und wurden in grausamer Weise mißhandelt. Mehr als 300 wurden hingerichtet. Die Verurteilten wurden in den Kielraum des Kreuzers 'Rumynija' geschleppt. Sie wurden einzeln in die Luke gerufen, mußten über das ganze Deck bis zum Schafott an den Reihen der Matrosen vorbeipassieren, welche ihnen die Kleider vom Leibe rissen, sie beschimpften und schlugen. Auf dem Schafott wurd en sie von den Matrosen zu Boden geworfen und an Händen und Füßen gefesselt. Dann wurden ihnen langsam die Ohren, Nasen, Lippen, Geschlechtsorgane und Hände abgeschnitten. Schließlich wurden die Opfer ins Schwarze Meer geworfen" (Kırımal, 1952, s. 165).

Nawet autorzy bardziej współczujący bolszewikom niż ich ofiarom są zmuszeni uznać te fakty. "Kpымy история отвела роль первому открыть позорную страницу гражданской войны - красную страницу террора" piszą rosyjscy historycy Krymu Aleksej i Wiaczesław Zarubinowie (Зарубин \& Зарубин, 1997, s. 66).

718 czerwca 1918 roku w Zatoce Cemeskiej załogi zatopiły 14 statków z pełnym uzbrojeniem, tylko małą część przypisanej do Sewastopolskiego portu floty bolszewicy przeprowadzili do Noworosyjska (patrz: Королев, 1994). 
mi Krymu (nawet w obliczu słabych pod względem militarnym rumuńskimi okupantami był on absolutnie bezradny); w powojennych czasach pokoju wyróżniał się, nawet wśród innych miast "rosyjskiego Krymu”, brudem, zaniedbaniem, niechlujstwem fizycznym, zacofaniem kulturowym.

Przy tym „rosyjski Krym” - to nieposkromiona zarozumiałość, przekonanie o wyższości rosyjskiego ducha (nie można nawet powiedzieć „rosyjskiej kultury”, ponieważ prawdziwej wysokiej rosyjskiej kultury nigdy nie było na Krymie), tępa oschłość w stosunku do sąsiadów, zażarta ksenofobia. Nienawidzi on (i jednocześnie boi się) Turków i Amerykanów, Żydów i Niemców, Ukraińców i muzułmanów - i nie ma końca tej liście, od czasu do czasu zmieniają się tylko priorytety. Żaden głos nie odezwał się z tego "rosyjskiego Krymu" ani w 1944 roku, ani w latach powojennych w obronie Tatarów krymskich i innych grup etnicznych (Niemców, Greków, Bułgarów, Ormian) poddanych totalnym stalinowskim deportacjom, po prostu nie zauważono ich nieobecności i zniknięcia - tak samo jak niemieccy obywatele Trzeciej Rzeszy nie zauważali zniknięcia Żydów i Romów z miast Niemiec, nie chcąc niepokoić swojego sumienia niezręcznymi pytaniami. Zresztą ta Trzecia Rzesza nie była w takim stopniu jednomyślna i miała swoich, co prawda nielicznych, bohaterów ruchu oporu, swego Thalmanna ${ }^{8}$, swego Schenka von Staufenberga ${ }^{9}$, swego Schindlera, którego "listy" 10 uratowały życie wielu ludzi skazanych na zagłade, natomiast "rosyjski Krym" - żadnego człowieka, który miałby odwage potępić stalinowską politykę deportacji i uratować w ten sposób rosyjski honor narodowy ${ }^{11}$.

Ale za to "rosyjski Krym” nieźle dorabiał się na tragedii deportowanych, bezwstydnie przywłaszczając ich domy i mienie (bez najmniejszego zamiaru, by oddać zrabowany łup) i wykazał chwalebną czujność (za Chruszczowa, za Breżniewa itd.), kiedy pierwsi śmiałkowie ze środowiska zesłanych Tatarów krymskich próbowali wrócić do ojczyzny, chociażby jedną nogą stąpnąć na ziemię rodzimą. Takich śmiałków śledzili, denuncjowali, łapali w hotelach, na dworcach, lotniskach, bili na posterunkach i w komisariatach milicyjnych, wyrzucali z Krymu, najbardziej upartych zabijali albo doprowadzali do samobójstwa, jak to stało się z chłopem tatarskim Musą Mamutem, który 23 czerwca 1978 roku zdecydował się na samospalenie (patrz: Р. Джемилев, 1986). I to wszystko robili własnymi rękami ci sami "Rosjanie Krymu”, którzy dzisiaj najgłośniej krzyczą o swojej miłości do Krymu i o swoim prawie, by decydować o losach tej ziemi. Taki rosyjski patriotyzm miał charakter wrogi ludziom i przestępczy, i do dziś nikt z jego entuzjastów nie wyraził skruchy i nie odpowiedzit przed sądem za swoje przestępstwa i haniebne czyny.

Obok zagarnięcia cudzego mienia z lat 40., na przełomie wieków XIX i XX aktywizowały się - w większej skali i na bardziej solidnej podstawie - nowe formy wzmocnienia socjalnej bazy rosyjskiej ludności Krymu w wyniku podziałów własności kołchozowej i prywatyzacji gruntów; odbywał się ten proces wyłącznie w rosyjskich interesach, pośród ludności rosyjskiej (przesiedleńców różnych czasów), nie dopuszczano do udziału w tym procesie ani Tatarów krymskich, którzy wracali do swojej ojczyzny po upadku reżymu komunistycz-

\section{-.....}

8 Ernst Thälmann (1866-1944) - w latach 1925-1933 deputowany Reichstagu, podczas panowania reżymu nazistowskiego więzień berlińskiego Moabitu, stracony w obozie Buchenwald.

9 Klaus Schenk von Staufenberg - jeden z uczestników nieudanego zamachu na Hitlera 20 lipca 1944 roku; stracony przez nazistów.

10 Świat dowiedziat się o tym z filmu Stevena Spielberga Lista Schindlera (1993).

11 W podziemiu dysydenckim, dokąd $w$ latach 70 . XX wieku przemieścito się centrum ruchu narodowego Tatarów krymskich (ruchu w obronie praw człowieka, w celu rehabilitacji narodu krymsko-tatarskiego i jego powrotu z miejsca zestania do ojczyzny) Tatarzy krymscy mieli dzielnych, walecznych i czcigodnych sojuszników - tak pośród Rosjan (Andriej Sacharow, Lidia Czukowskaja, Ludmiła Aleksiejewa, Siergiej Kowalow, na uchodźstwie w Ameryce Aleksander Niekricz), jak i Ukraińców (general Piotr Grigorienko) i wspaniałych ludzi innych narodowości, ale żadnego przedstawiciela "rosyjskiego Krymu”. 
nego, ani przedstawicieli innych mniejszości etnicznych i narodowych, za którymi władza rosyjska (powiązana z Kremlem administracja Autonomicznej Republiki Krymu) oraz pozapaństwowe ugrupowania rosyjskich „patriotów” (szowinistów) nie uznawały prawa do ziemi krymskiej.

Osobną uprzywilejowaną grupę "Rosjan Krymu” - nie zawsze etnicznych Rosjan, ale uważających, że są Rosjanami - tworzyli emeryci ze struktur armijnych i organów bezpieki, wywiadu, milicji jeszcze radzieckiego formatu, stojący na różnych poziomach - od szeregowych wartowników - tak zwanej wochry (ochrony zbrojnej), ze stażem pracy w więzieniach i obozach karnych - do wyższej wojennej, partyjnej, urzędniczej generalicji. Ci ludzie („weterani”, „bohaterzy”, „kombatanci”) dostawali na Krymie mieszkania z wygodami i dacze, podwyższone emerytury i renty i tworzyli we wszystkich regionach, szczególnie na południowym wybrzeżu Krymu, znaczną warstwę socjalną, na której zawsze mogła się opierać reakcja polityczna, natchnięta ideami rewanżu (odbudowy na nowo Związku Radzieckiego i reżymu komunistycznego). Bezpośrednio przylegał do tej warstwy liczny rosyjski personel obsługujący skupiony w sanatoriach i domach wypoczynkowych, na daczach rządowych krymskiego „wszechzwiązkowego uzdrowiska” („всесоюзной здравницы”), który karmił się z pańskiego stołu.

Dążenia tych "sił patriotycznych" do połączenia Krymu z Federacją Rosyjską miały podszewkę polityczną. To była nostalgia za przeszłością radzie cką, nastroje odwetowe: „Wstecz - do Związku Radzieckiego!”, „Wstecz - do Stalina!", a jeżeli na razie takie marzenia są jeszcze nieziszczalne, to przynajmniej „Wstecz - do Rosji!", „Wstecz - do Putina!". Wzmacniały się takie nastroje, które osiągnęły swój szczyt w histerii patriotycznej, towarzyszącej przeprowadzeniu referendum 16 marca 2014 roku, nie w sposób żywiotowy, lecz z pomocą eks portu organizowanego z Rosji - ideologicznego, wojennego, duchownego (ofensywa Rosyjskiej Cerkwi Prawosławnej, która założyła na Krymie swoją diecezję z wielkim patriotą Rosji arcybiskupem Łazarem na czele) i materialnego (obietnicy lepszych wypłat emerytalnych i rentowych podniecały rosyjsko-patriotyczne nastawienie merkantylnej części mieszkańców Krymu, i pewne inwestycje - kosztem wszystkich podatników Federacji Rosyjskiej - do krymskiego systemu finansowego, przy przejściu z ukraińskiej grzywny na walutę rublową, i socjalnego - Rosja w rzeczywistości robiła). Płomień wielkorosyjskiego szowinizmu, nazywanego dla przyzwoitości „rosyjskim patriotyzmem", szalejący na Krymie, łączył się nierozerwalnie z egoizmem i konsumpcyjnymi rachubami, nadziejami na utrzymanie rosyjskiego państwa.

Istote takiego patriotyzmu bardzo precyzyjnie scharakteryzował lider narodu krymskotatarskiego Mustafa Dżemilew, który od dawna już przewidywał możliwe tragiczne skutki jego działania i próbował wypracować strategię oporu. „Если русские Крыма хотят домой, в Россию - mówił on - могут уезжать, их никто не держит, но прихватить с собой по дороге домой нашу родину - Крым - мы им не позволим ${ }^{12}$. Niestety rozwój wydarzeń poszedł według najbardziej czarnego scenariusza, i podpisana w Moskwie przez prezydenta Federacji Rosyjskiej i krymskich separatystów, którzy dokonali - w oparciu o rosyjskie siły zbrojne - przewrotu państwowego, Umowa z 18 marca 2014 roku o wejściu Krymu w skład Federacji Rosyjskiej oznacza złodziejską próbę odejśćciaz jednego państwa i wejścia do innego państwa razem z obcą ziemią.

\section{....}

12 Tekst wystąpienia Mustafy Dżemilewa (w języku rosyjskim) na spotkaniu z deputowanymi Reichstagu FRN w Berlinie 5 lipca 2011 roku w prywatnym archiwum autorki, która uczestniczyła w tym spotkaniu w składzie delegacji krymsko-tatarskiej. 
Próba Kremla, aby oderwać Krym od państwa ukraińskiego - nie tylko wbrew państwowym interesom Ukrainy, której Rosja między innymi gwarantowała integralność i nienaruszalność granic, ale także bez wyjawienia woli rdzennego narodu Krymu - Tatarów krymskich, wbrew tej woli, zademonstrowanej przez bojkot referendum, wbrew życiowym interesom narodu krymsko-tatarskiego, który wypracował strategię sojuszu z postępowymi siłami narodu ukraińskiego i dla którego istnienie w ramach państwa ukraińskiego było mniejszym złem niż przynależność do Rosji - jest bardzo niebezpiecznym eksperymentem w międzynarodowym kontekście. Związek Radziecki rozpadł się w 1991 roku prawie bez przelewu krwi (i ten fakt był swego rodzaju cudem i wielkim szczęściem dla milionów ludzi, którzy uniknęli koszmarów wojny) o granice 15 dawnych republik „związkowych”, które przekształciły się - w tych granicach! w nowe państwa niezależne, uznane przez wspólnotę światową. Nigdzie te granice nie były idealne, bezsprzeczne, bezsporne, absolutnie "sprawiedliwe”. W tym sensie i sprawiedliwość aktu 1954 roku, którym Rosja „podarowała” Krym „swojej młodszej siostrze" - Ukrainie, może budzić wątpliwości z punktu widzenia jego legalności prawnej i moralnej, ale nie może być nic gorszego niż próba jednostronnej i przymusowej zmiany, ponownego rozpatrywania tych granic na korzyść tylko jednej strony (Rosji) i przeciwko interesom jej słabszych partnerów. Wtedy n ie s p ra wi edli wość staje się jeszcze większa.

Żadnego zagrożenia, które mogłoby usprawiedliwić radykalne kroki w obronie praw człowieka, Rosjanie z Krymu na całej przestrzeni jego rozwoju w ramach ukraińskiego państwa nigdy nie doznawali ani ze strony Kijowa (ukraińskiej władzy), ani ze strony dobrze zorganizowanego narodowego ruchu Tatarów krymskich, zawsze działającego w ramach konstytucyjnnych i nigdy niesięgającego po metody gwałtu i przymusu. Z roku na rok Rosjanie na Krymie niczego nie tracili, tylko dostawali, a część z nich korzystała z absolutnie niezasłużonych przywilejów. Ich patriotyzm miał charakter destrukcyjny: kochali oni nie tyle Krym, do którego kultury i gospodarki nie byli w stanie wnieść dorobku, ile znajdującą za historycznymi i jurydycznymi granicami Krymu "matuszke Rosję”, do której bezgranicznych posiadłości marzyli oni dołączyć piękny kawałek krymskiej ziemi, żeby bezwzględnie eksploatować jego przyrodę, korzystać z jego bogactw i z jego strategicznego położenia, istotnego w planach dalszej ofensywy na Południe i nowych zaborów w Azji i Europie. Jako zaborcy, okupanci i kolonizatorzy (bezpośredni albo pośredni spadkobiercy, potomni zaborców XVIII-XX stuleci), gotowi kontynuować i w XXI wieku imperialną politykę kolonizacji Krymu, nie mają oni żadnego prawa decydować o losach i prawnym statusie Krymu ani w jakichkolwiek referendach, ani poza referendami, tym bardziej decydować przy zupełnym lekceważeniu narodu krymsko-tatarskiego, dla którego Krym jest jedyną ojczyzną. Próba państwowej i kulturowej rusyfikacji tej ziemi jest przestępstwem, którego nie da się zaakceptować ani w historycznym i kulturowym kontekście, ani z moralnego punktu widzenia, ani w zakresie prawa międzynarodowego, ani w kontekście zadań europejskiego i światowego bezpieczeństwa.

Jeżeli państwo ukraińskie w najcięższych czasach własnego formowania w latach 90. XX wieku było jedynym w całej przestrzeni postradzieckiej, które wzięło na siebie przynajmniej część odpowiedzialności i troski o wracających do ojczyzny Tatarów krymskich, zapewniając im obywatelstwo ukraińskie bez biurokratycznej mitręgi ${ }^{13}$ i dzieląc z nimi do-

\footnotetext{
13 Ustawa Ukrainy „O zmianach w Ustawie Ukrainy 'O obywatelstwie Ukrainy” nr 210/97 z 16 kwietnia 1997 roku („Закон України Про внесення змін до Закону України «Про громадянство України»”, 1997) zagwarantowała ułatwione procedury nadawania obywatelstwa Ukrainy osobom poddanym przymusowej deportacji z Krymu w 1944 roku oraz ich potomkom i członkom rodzin.
} 
słownie okruchy swego niebogatego budżetu, to Federacja Rosyjska, w której imię była dokonana deportacja 1944 roku i likwidacja Krymskiej ASSR ${ }^{14}$, odsunęła się od jakiejkolwiek pomocy Tatarom krymskim.

\section{BIBLIOGRAFIA}

Kırımal, E. (1952). Der nationale Kampf der Krimtürken mit besonderer Berücksichtigung der Jahre 1917-1918. Emsdetten: Lechte.

Sejdamet, D. (1930). Krym. Przeszłość, teraźniejszość i dążenia niepodległościowe Tatarów krymskich. Warszawa: Wydawnictwo Instytutu Wschodniego.

Возгрин, В. (1992). Исторические судьбы крымских татар. Москва: Мысль.

Волошин, М. (1992). Культура, искусство, памятники Крыма. W H. Ибадуллаев (Red.), забвению не подлежит: из истории крымскотатарской государственности и Крыма (ss. 55-68). Казань: Татарское книжное издательство.

Гайворонский, А. (2003). Созвездие Гераев: краткие биографии крымских ханов. Симферополь: Доля.

Губогло, М., \& Червонная, С. (1992). Крымскотатарское национальное движение (Т. 1-2). Москва: циМО.

Джемилев, М. (2014, kwiecień 1). Текст выступления Мустафы Джемилева на закрытом заседании СБ ООН в г. Нью-Йорк, США, 31 марта 2014 года. Pobrano 18 grudnia 2015, z http://tiny.cc/ogcf7x

Джемилев, Р. (1986). Живой факел: самосожжение Мусы Мамута. Нью-Йорк: Фонд Крым.

Закон України Про внесення змін до Закону України "Про громадянство України». (1997). Відомості Верховної Ради України, 23, 363-374. Pobrano 18 grudnia 2015, z http:// zakon4.rada.gov.ua/laws/show/210/97-\%D0\%B2\%D1\%80

Зарубин, А., \& Зарубин, В. (1997). Без победителей: из истории гражданской войны в Крыму. Симферополь: Таврия.

Королев, В. (1994). Черноморская трагедия: Черноморский флот в политическом водовороте 1917-1918 г2. Симферополь: Таврия.

Маркевич, А. (1928). Переселения крымских татар в Турцию в связи с движением населения в Крыму. Известия Академии наук СССР. Отделение гуманитарных наук, 7, 375-405.

Національний склад населення АРК та його мовні ознаки: за даними всеукраїнського перепису населення 2001 року. (2003). Сімферополь: Державний комітет статистики України. Головне управління статистики в АРК.

Никольский, П. (1929). От Крымского ханства до наших дней: историко-экономический очерк. Симферополь: Крымгосиздат.

14 Utworzona na podstawie „leninowskiego” dekretu z 18 października 1921 roku w ramach Federacji Rosyjskiej Krymska Autonomiczna Socjalistyczna Republika Radziecka, uważana przez Tatarów krymskich, za formę ich narodowego państwowego samostanowienia, została zlikwidowana przez Uchwałe Prezydium Najwyższej Rady RFSRR z 30 czerwca 1945 roku „O tym, żeby przeksztatcić Krymską ASRR w obwód Krymskie" (О преобразовании Крымской АССР в Крымскую область). Przed tym powstała znacząca Uchwała Prezydium Najwyższej Rady RFSRR „O zmianie nazw (przemianowywaniu) rejonów i rejonowych ośrodków Krymskiej ASRR (О переименовании районов и районных центров Крымской ACCP) z 14 grudnia 1944 roku. Na podstawie tej Uchwały została zniszczona w gruncie rzeczy cała historyczna tatarska toponimia Krymu: rejon Ak-Meczet stał się Czarnomorskim, Ak-Szejch - Razdolnienskim, Ikczy - Sowieckim, Kaeasu-Bazar Biełogorskim i tak dalej (oba dokumenty są opublikowane w: Губогло \& Червонная, 1992, s. 47). 
Dzhevilev, M. (2014, April 1). Tekst vystuplenîa Mustafy Dzhemileva na zakrytom zasedanii SB OON v g. Nî-lorke, SShA, 31 marta 2014 goda. Retrieved December 18, 2015, from z http://tiny.cc/ogcf7x

Dzhemilev, R. (1986). Zhivol fakel: samosozzhenie Musy Mamuna. NTû-lork: Fond Krym.

Gaivvoronskiï, A. (2003). Sozvezdie Geraev: kratkie biografii krymskikh khanov. Simferopol': Dolia.

Guboglo, M., \& Chervonnaîa, S. (1992). Krymskotatarskoe natsional'noe dvizhenie (Vols. 1-2). Moskva: TSIMO.

Kırımal, E. (1952). Der nationale Kampf der Krimtürken mit besonderer Berücksichtigung der Jahre 1917-1918. Emsdetten: Lechte.

Korolev, V. (1994). Chernomorskaia tragedilia: Chernomorskii flot v politicheskom vodovorote 1917-1918 gg. Simferopol': Tavrîa.

Markevich, A. (1928). Pereselenía krymskikh tatar $\vee$ Turtsiîu $\vee$ sviazzi $s$ dvizheniem naselenía v Krymu. Izvestî́a Akademii nauk SSSR. Otdelenie gumanitarnykh nauk, 7 , 375-405.

Natsional'nyĭ skład naselennia ARK ta ioho movni oznaky: za danymy vseukraïn'koho perepysu naselennia 2001 roku. (2003). Simferopol': Derzhavniï komitet statystyky Ukraïny. Holovne upravlinnîa statystyka v ARK.

Nikolskiï, P. (1929). Ot Krymskogo khanstva do nashikh dneĭ: istoriko-ékonomicheskii ocherk. Simferopol': Krygosizdat.

Sejdamet, D. (1930). Krym. Przeszłość, teraźniejszość i dążenia niepodległościowe Tatarów krymskich. Warszawa: Wydawnictwo Instytutu Wschodniego.

Voloshin, M. (1992). Kul'tura, iskusstvo, namiatniki Kryma. In N. Ibadullaev (Ed.), Zabveniiu ne podlezhit: iz istorii krymskotatarskol gosudarstvennosti i Kryma (pp. 55-68). Kazan': Tatarskoe knizhnoe izdatel'stvo.

Vozgrin, V. (1992). Istoricheskie sud'by krymskikh tatar. Moskva: Mysl'.

Zakon Ukraïny Pro vnesennia zmin do Zakonu Ukraïny "Pro hromadianstvo Ukraïny". (1997). Vidomosti Verkhovnoï Rady Ukraïny, 23, 363-374. Retrieved December 18, 2015, from http://zakon4.rada.gov.ua/laws/show/210/97-\% D0\% B2\% D1\%80

Zarubin, A., \& Zarubin, V. (1997). Bez pobediteleĭ: iz istorii grazhdanskoĭ voìny $v$ Krymu. Simferopol': Tavrîa. 